\title{
Samtidsteologiens fokus og horisont
}

\author{
Professor Niels Henrik Gregersen
}

\begin{abstract}
In this response to Asle Eikrem's discussion of my program for "Systematic Theology as Contemporary Theology" (DTT 2008, 290310), I lay out my principled reasons for maintaining the distinction between Theology1, 2 and 3. While I find Eikrem's proposals concerning the relation between the semantics and the pragmatics in Theology1 revealing, I argue that systematic theology should not be understood as a purely theoretical metaphysics.
\end{abstract}

Key words: Asle Eikrem - Lorenz B. Puntel - systematic theology.

Asle Eikrem har leveret en indgående analyse af mit forslag til en bestemmelse af dogmatik som samtidsteologi og har herunder fremlagt sine egne forslag til modellens videreudvikling. ${ }^{1}$ Der er tale om et skarpsindigt arbejde, og jeg er derfor glad for at kunne svare på artiklen på den korte plads, der står til min rådighed.

Jeg kan tilslutte mig en række af Eikrems forslag til præcisioner, men er skeptisk over for hans forstålse af dogmatik som metafysik. Jeg medgiver gerne, at en "metafysisk orientering" altid hører med til teologiens horisont, men mener ikke, at samtidsteologi altid må drives inden for rammen af en "ekspliceret metafysik" (Eikrem 2011, 166, jf. 152). Min frygt er, at Eikrems rekonstruktion af min model fører til, at samtidsteologien mister sin indholdsbestemthed. Eikrem synes ikke villig til at foretage bevægelsen fra den mere konkrete Teologi1 (i nært samarbejde med den praktiske teologi) til den mere abstrakte Teologi3 (i nært samarbejde med religionsfilosofien). Eikrems eget forslag indebærer, at dogmatikkens arbejde skal være styret af en metafysisk problemstilling fra først til sidst. Men her må der skelnes mellem dogmatikkens fokus og dens horisont.

Ligeledes må der skelnes mellem et program og en position. Med samtidsteologien som "program" har jeg ønsket at præsentere en model for en afgrænsning af et bestemt forskningsområde, i dette tilfælde dogmatikken. Et sådant program skal for det første kunne rumme flere forskellige teologiske positioner (nogle mere, andre mindre metafysisk orienterede). Et program må i et vist omfang være "i overensstemmelse med allerede gældende forskningspraksis", ${ }^{2}$ samtidig med,

1. Asle Eikrem, "Dogmatikk som samtidsteologi. En kritisk videreutvikling af N.H. Gregersens program”, DTT 74:2 (2011), 152-166. - I det følgende oversættes citater herfra til dansk.

2. Niels Henrik Gregersen, "Dogmatik som samtidsteologi”, DTT 71:4 (2008), 290-310 (296). 
at modellen ønsker at være vejledende for, hvad der er fagets snævrere fokus og dets videre horisont. Fokus i min model ligger i kristendommen som en levet religion i samtiden.

For det andet er det afgørende, at et program er praktisabelt. Der må ikke stilles så idealiserede krav til et forskningsfelt, at fagets opgaver bliver umulige at løse i praksis. Et fagområde skal være håndterbart for dets udøvere, og der kan ikke appelleres til særlige erkendelser af mystisk eller trosmæssig karakter eller til særlige konfessionelle bindinger. Heller ikke kan der forudsættes en enighed om en bestemt metafysisk "livssynsteori" (således Eikrem 2011, 162).

Endelig er det for det tredje afgørende, at et fag har et bestemt og afgrænset genstandsområde. Dogmatikkens fokus er ikke religion og livssynstolkning i almindelighed (heller ikke "virkelighedens religiøse dimension", Eikrem 2011, 166), men derimod kristendommen i dens forskellige repræsentative former. Denne genstandsorientering forbinder samtidsteologien med andre kulturvidenskabelige discipliner, samtidig med at teologiens normative interesse forbinder den med socialvidenskaberne.

\section{Forholdet mellem semantik og pragmatik på teologi1-niveau}

Min model skelner mellem tre niveauer for samtidsteologien. Teologil rummer eksplicerende genbeskrivelser af den levede kristendom gennem dens typiske praksisformer, fx dåb, skriftlæsning, velsignelse og bøn. Teologi2 (dogmatik i ordets sædvanlige forstand) rummer mere systematiserende genbeskrivelser af kristendommens indre sammenhæng med henblik på at kunne formulere velgennemtænkte forslag til, hvordan kristendommen bedst kan eller kunne forstås i dag. Endelig drejer Teologi3 sig om at sætte kristendommen i relation til andre religioner og livstydninger i samtiden med henblik på at opfange udfordringer og selv svare på disse (Gregersen 2008, 307-10).

Eikrems første spørgsmål drejer sig om, hvordan jeg forstår forholdet mellem det semantiske og det pragmatiske i bestemmelsen af Teologi 1. Han spørger, om det dogmatiske arbejde af første orden "drejer sig om at eksplicere, hvad mennesker gør, hvad de siger, eller hvad de siger i kraft af, hvad de gør" (Eikrem 2011, 44). Dette er ganske rigtigt ikke er blevet tilstrækkeligt afklaret i min artikel, og det er klargørende, når Eikrem præciserer, at Teologi1 handler om "at eksplicere, hvad kristne mennesker udtrykker, når de gør noget”(Eikrem 2011, 155). Ligeledes må jeg give Eikrem ret $i$, at allerede Teologil rummer en teoretisk fremstilling fra et tredjepersonsperspektiv ("Det forholder sig sådan, at kristne mennesker siger/gør det- 
te')" (Eikrem 2011, 154). Teologil ville ellers kunne forveksles med en religionssociologi eller -psykologi, hvorved Teologil ville dreje sig om at samle forskellige informanters udsagn om, hvad de alt sammen føler eller tænker fx under en dåbshandling. Men Teologil drejer sig ikke om, hvad enkeltpersoner tænker og mener, men om at præsentere en "tyk" genbeskrivelse af, hvad der udtrykkes med handlingen "what is getting said", som det elegant formuleres af Clifford Geertz. ${ }^{3}$ Min pointe vil så til gengæld være, at den teologiske eksplikation af sammenhængen mellem pragmatikken (dåben som handling) og semantikken (dåbens betydning) i princippet skal kunne genkendes af samtidens kristne mennesker. Eikrem har ret $\mathrm{i}$, at der aldrig vil være identitet mellem et førstepersons brugerperspektiv og et teoretisk tredjepersonsperspektiv. Men adskilles kan de heller ikke.

Tilsvarende vil der også være en forskel mellem samtidsteologens og fx etnografens perspektiv. Dogmatikkens fokus drejer sig om dåbens "store" semantik og om dåbens typiske praksisformer, hvorimod dogmatikken normalt ikke interesserer sig for den "lille" semantik (hvad den enkelte opfatter situationen i en bestemt sammenhæng) eller for den konkrete pragmatik (fx kirkerummet, dåbens hvornår og hvorhenne, præstens rolle og stemmeføring, deltagernes grad af participation, etc.). Sådanne spørgsmål kan ganske vist vise sig at være dogmatisk relevante (er det for eksempel uproblematisk at arrangere lørdagsdåb for familien alene?). Men det er ikke sådanne spørgsmål, der står i centrum for samtidsteologiens eksplikation af kristendommens primære livsytringer. Dogmatikkens fokus er den samtidige kristendom i (nogle af) dens representative skikkelser - uden dermed at forudsætte en teologisk essentialisme. For så vidt som dogmatikken på Teologi1-niveau søger efter de mere typiske aspekter ved handlinger og deres tolkninger, vil der her være en forskel i fokus i forhold til de "tykke beskrivelser" af helt konkrete sprog-og praksisformer, som antropologer à la Geertz vil interessere sig for.

\section{"There's a crack in everything: that's how the light gets in"}

Eikrem foreslår nu en model for en "lingvistisk-pragmatisk eksplikation" (en præcisering af Teologi1), som han har hentet fra Münchener-filosoffen Lorenz B. Puntel. Eikrem er med på, at kristne praksisser hører med til samtidsteologiens felt: "For optimalt at forstå, hvad kristne mennesker gør, må en række sprogeksterne (asemantiske) fak-

3. Clifford Geertz, The Interpretation of Cultures (New York: Basic Books 1973), 10, citeret Eikrem $(2011,155)$. 
torer tages med i betragtning (faktorer som bestemmer det sproglige subjekts relation til andre subjekter, situation, kontekst, osv.)" (Eikrem 2011, 157). En sproghandling såsom en liturgisk bøn er fx ikke identisk med det, som bønnen faktisk siger. Men ligesom pragmatik ikke kan reduceres til semantik, kan semantik ikke reduceres til pragmatik. Ifølge Eikrem består den semantiske eksplikation endvidere ikke kun i det, der faktisk gøres eller udtrykkes, men i det, som overhovedet kan udtrykkes (Eikrem 2011, 157). Når denne skelnen mellem den faktisk udtrykte mening og den potentielle mening er vigtig for Eikrem, skyldes det, at både kristne handlinger og udsagn kan fremstå som usammenhængende for teologen. Det er rigtigt. Men heraf drager Eikrem den slutning, at også Teologil-fremstillingen må være "kohærent, dersom den skal kunne kaldes en videnskabelig (teoretisk) fremstilling" (2011, 156).

Her er jeg faktisk uenig. Teologens lyttende Teologi1-tolkning af, hvad der siges og gøres i den levede kristendom, må også være opmærksom på brudfladerne i den levede kristendom. I religiøs praksis findes kun meget sjældent helt rene og klare udsagn. Hele øvelsen med at skelne mellem Teologi1 og 2 skal netop til for ikke at homogenisere troens udtryk for tidligt. Kravet om kohærens sætter først ind med den mere systematiske fremstilling på niveau 2. Idéen om en kristen kommunikation, som er "livsverdensmæssigt fuldt bestemt" (Eikrem 2011, 156) bygger på en idealisering, der dårligt kan andet end at øve vold imod det religiøse livs heterogenitet.

I religiøs praksis er polydoksi et udbredt fænomen. ${ }^{4}$ Men også det liturgiske sprog er gennemtrængt af udsagn, der giver afkald på sproglig entydighed. Det skyldes, at det religiøse sprog er metaforisk, dvs. spiller på fællesmenneskelige erfaringer, samtidig med at ordenes betydninger overskrides, når de bruges om Gud. Samtidig findes der også eksempler på et mere principielt afkald på de medbragte referencerammer, som i doksologien. ${ }^{5}$ Efter prædiken i folkekirken hører vi: "Lov og tak og evig ære være dig vor Gud, Fader, Søn og Helligånd, du,

4. Se fx Cecilie Rubow og Christine Tind Johannesen-Henry, "Variationer af liv i døden: Transcendenser i hverdagslivets (nye) polydoksi", Tidsskrift for Forskning i Sygdom og samfund 7:12 (2010).

5. Se Wolfhart Pannenberg, "Analogie und Doxologie", Grundfragen systematischer Theologie (Göttingen: Vandenhoeck \& Ruprecht 1967), 181-201. I denne forstand er der en apofatisk dimension i al tale om Gud inden for kristen traditon. Dette gør ikke talen om Gud "meningsløs", som forudsat af Eikrem (2011, 158 n. 14). Der findes ikke (som det ofte antages) to typer af teologi, en katafatisk bestemt via positiva og en apofatisk bestemt via negativa. Også fx Pseudo-Dionysios' Theologia mystica begynder med en analogisk tale om Gud, før skriftet ender i en doksologisk tale til Gud. Som påvist af John Macquarrie, In Search of Deity: An Essay in Dialectical Theism. The Gifford Lectures 1983-4 (London: 
som var, er og bliver én sand treenig Gud, højlovet fra første begyndelse, nu og i al evighed. Amen." Ingen nok så klog samtidsteolog vil kunne eftervise, hvordan en sådan lovprisning kan sættes i en entydig relation til alle andre udsagn om tilværelsen som helhed. I Teologi1 artikuleres dermed også grænserne for, hvad der lader sig rationalisere.

Faren for en rationel homogenisering bliver endnu tydelige, når Eikrem i forlængelse af Puntel (og som en præcisering af Teolog 2 og 3) gør gældende, at vi må bevæge os videre fra en lingvistisk-pragmatisk eksplikation til en semantisk-ontologisk eksplikation, dvs. en eksplikation af den virkelighedsforståelse, som er forudsat i hver enkelt kristen sproghandling. Dogmatik må derfor drives som metafysik, eller som Eikrem mere forsigtigt siger: må være "metafysisk orienteret" (2011, 162-63). Med den sidstnævnte kvalificering er jeg enig med Eikrem. Derfor går der på min figurtegning over Teologi1, 2 og 3 (Gregersen 2008, 309) også indflydelser fra Teologi3 nedad til Teologi2 og Teologi1 (markeret med stiplede pile). Men jeg står fast på min hovedpointe om, at teologiens primære fødekæde går nedefra og op (markeret med de brede pile).

\section{Om cirkulationen mellem Teologi1, 2 og 3}

Ifølge Eikrem er problemet med min distinktion mellem Teologi1, 2 og 3, at jeg så at sige udsætter de metafysiske spørgsmål til teologi 3. Min bestemmelse af Teologi 1 og 2 er altså metafysisk underbestemt, fordi de forsøger at afgrænse et bestemt genstandsområde - om det nu er dåb eller doksologi på Teologi1-niveau eller større temaer såsom skabelse og kristologi i på Teologi2-niveau. Jeg er her enig med Eikrem i, at eksplikationsopgaven fortsætter på teologi2 og 3-niveau, hvorfor jeg også taler om en "genbeskrivelse" i forbindelse med dogmatikkens systematiserende teologi2 (Gregersen 2008, 309) - og dette er forudsat i min beskrivelse af Teologi3. Men Eikrems indvending er, at det komparative element er lige så grundlæggende for Teologi1 og 2 som for Teologi3. Man kan ifølge Eikrem ikke genfremstille kristendommens indre sammenhæng uden at præcisere kristendommen i forhold til andre livssyn. "Mens Gregersen mener, at hensynet til ikke-kristne semantikker/pragmatikker ikke er konstitutiv for teologi af første og anden orden, men derimod kun for teologi af tredje orden, mener jeg, at ikke-kristne semantikker/pragmatikker også har relevans for arbejdet inden for teologi af første [og anden] orden” (Eik-

SCM Press 1984), gælder dette også i den filosofiske tradition fra Plotin til Heidegger, med G.W.F. Hegel og A.N. Whitehead som markante undtagelser. 
rem 2011, 159). Eikrem har her en pointe, eftersom intet arbejde foregår isoleret. Der foregår som sagt en cirkulation mellem de tre niveauer. Men jeg vil mene, at der kun vil være tale om ad hoc-komparationer med andre livssyn, når man på Teologi2 niveau skal præsentere sit bud på, hvad kristendom er og kunne betyde i dag. Der er netop tale om sideblik, ikke om de store systematiske udfoldelser, som bør føres i de specialiserede diskurser på niveau 3 (fx. vedr. teologi og naturvidenskab, kristendom og islam, etc.). Jeg ser kort sagt ikke nogen gevinst ved at udviske konturerne mellem de tre niveauer. Man behøver ikke at redegøre for alle denne verdens initiationsriter for at kunne eksplicere dåbshandlingens betydning, og man behøver ikke at redegøre for Jesus-skikkelsen gennem en komparation med Buddha og alle andre frelserfigurer. Alt er tilladt og kan være oplysende. Men ikke alt er lige nødvendigt i alle kontekster.

Jeg har kort sagt mange gode iagttagelser at takke Eikrem for. Men resultatet af Eikrems videreudvikling af min model bliver, at forskellene viskes ud mellem Teologi 1, 2 og 3. Hvis man kræver en fuldstændig transparens på Teologil-niveau og samtidig kræver en gennemført komparation på niveau $1 \mathrm{og} 2$, så opløses modellen - og taber praktisk anvendelighed. Til sidst kan kun den, der kan tilslutte sig en universalistisk metafysik à la Puntel, anvende modellen. ${ }^{6}$ Men faget dogmatik skal også kunne udøves af den, som ikke er hegelianer.

6. Jeg har med udbytte læst Puntels tidligere arbejder til kohærens-teorien og er imponeret over Eikrems indlæsthed i Puntels nyere arbejder. Samtidig må jeg pege på nogle grunde til, at hans metafysik er mindre velegnet til mine formål: (1) Puntel forstår sin filosofi som "pure theory", idet han udtrykkeligt afviser alskens terapeutiske eller pragmatiske formål for filosofien. Det program for dogmatikken, som jeg har fremlagt, må derimod beskrives som både analytisk og terapeutisk. (2) Puntels interesse i en teori om altings relationer til alt andet medfører, at hans teori ikke bliver meget afficeret af konkrete indhold. Jeg har her fundet mere gavn af Nicholas Reschers pragmatistiske metafysik, fordi Rescher - inspireret af C.S. Peirce snarere end Hegel - tilkender de empiriske videnskaber en grundlæggende betydning for filosofien. (3) Jeg er skeptisk over for en metafysik, der forudsætter et sammenfald mellem virkelighed og sproglighed, og som tilmed hævder at kunne artikulere "the interconnections between all its thematic components" inden for "the unrestricted universe of discourse". Mindre må kunne gøre det. Se Lorenz B. Puntel, Structure and Being: A Theoretical Framework for a Systematic Philosophy, translated by and in collaboration with Alan White (University Park, PA: Pennsylvania University Press 2008), 1, 8 og 10. 